\title{
REGULATORY AND LEGAL SUPPORT OF LAND REFORM IN UKRAINE
}

\author{
A. Zaika \\ Post-graduate student \\ Institute of Agroecology and Environmental Management of NAAS \\ (Kyiv, Ukraine) \\ e-mail:anastasia05091995@gmail.com \\ ORCID: https://orcid.org/0000-0002-4260-4190
}

The process of formation of the normative and legal support of land-agrarian reform in Ukraine in historical retrospect is covered.

It is established that the cause of the main problems in the reform implementation is the presence of Soviet vestiges in the legislation and politics of Ukraine.

It was looked into the state of lack of full institutionalization of constitutional land norms and the existence of a long-term moratorium on the sale of agricultural land, which negatively affected economic growth, investment, technology and production, the environment and living standards in rural areas, as well as their role in thriving corruption and shadow economy in the state.

A qualitatively new stage of regulatory and legal regulation of the agricultural land market, which began in 2020 with the adoption of the Law of Ukraine "On Amendments to Certain Legislative Acts of Ukraine on the Circulation of Agricultural Land» and related regulations, is analyzed.

Conclusions are made on the need and motivation for further development of legislation in the field of regulation of the market land and public relations.

The necessary directions for further reform and expansion of the regulatory framework are outlined.

Keywords: constitutional norms, land market, moratorium, shares, circulation of agricultural land, legislation.

\section{INTRODUCTION}

The Constitution of Ukraine has established that land, its interior, atmospheric air, water and other natural resources located within the territory of Ukraine, natural resources of its continental shelf, exclusive (marine) economic zone (abbreviated «land and its natural resources») are objects of property rights (possession, use and disposal) of the Ukrainian people. Every citizen has the right to use (not to own and to dispose of) natural objects of property of the people in accordance with the law. Property (of the Ukrainian people) is binding. Property should not be used to the detriment of man and society. The state provides protection of the rights of all subjects (citizens, their legal entities, including communal and state ones) property rights and management, social orientation of the economy. All the subjects of property rights are equal before the law. Land (and its natural resources) is the main national wealth, which is under special state protection. Ownership (private, communal and state) of land (plots of land) is guaranteed. This right is acquired and exercised by citizens, legal entities and the state exclusively in accordance with the law. Everyone has the right to own, to use and to dispose of their property (objects of civil rights), the results of their intellectual and creative activities. No one may be unlawfully deprived of property rights. The right of private property is inviolable. Compulsory alienation of objects of private property rights may be used only as an exception for reasons of public necessity, on the basis and in the manner prescribed by law, and subject to prior and full reimbursement of their value. The use of property may not harm the rights, freedoms and dignity of citizens, the interests of society; worsen the environmental situation and the natural qualities of the land (such damages are subject to full compensation) [1].

Such unique constitutionally declared transactions are subject to objective laws of animate and inanimate nature and society in terms of land use and its natural resources as natural objects and the main capital of the nation - for the benefit of the Ukrainian people, aimed at real formation and functioning of the structure of life and the corresponding legal and social and economic system in the state.

Land reform in the agricultural sector of the economy is the process of creating constitutionally motivated organizational, legal, economic, scientific and other social foundations for various forms of management, which results in the formation of cognitive agrarian land system acceptable for effective economic nature-saving activities on land. Land reform is a set of legal, 
economic, technical and organizational measures aimed at improving land relations, the transition to a new constitutionally motivated land system, which corresponds to the nature of the regulated socially-oriented market economy.

The so-called land reform in Ukraine has been going on since independence and the transition of the country's economy from an administrative-command system to democratic market relations based on private property.

However, during all the years (since the adoption of the Fundamental Law of Ukraine) there are no laws that would regulate the acquisition and implementation of land ownership (for land plots as objects of civil rights) and legal, environmental, economic and other relations (rights, obligations, requirements and regulations) on the «use» of natural objects of ownership of the Ukrainian people in the process of legal management (use) within specific land plots (boundaries) as economic objects.

According to the existing ideas of leading scientists on the transformation of the agricultural sector of the economy, in particular Dobriak D.S., Shkuratov O.I., the task and essence is defined: "The task of the reform in Ukraine is the redistribution of land with simultaneous transfer to private and collective ownership in the use of enterprises, institutions and organizations in order to create conditions for equal development of various forms of land management, the formation of a diversified economy, rational use and protection of land. The essence of the land reform is to create conditions for the equal development of various forms of land management through land redistribution. The land reform is changing the forms of land ownership, the structure of land tenure and land use in the agricultural sector. The land reform requires large-scale market transformations» [2].

It is also believed that in the process of market circulation (alienation and acquisition) of land plots there is a competitive change of landowners or land users. The dynamics of the agro-industrial complex development, land relations and the national economy in general depend on the creation of an efficient market for agricultural land in Ukraine.

At the same time, today in the scientific community there is a discussion on determining the place of ownership of the Ukrainian people in the system of modern property rights, recognition and legal definition of the Ukrainian people as a subject of ownership of natural resources due to the complexity and ambiguity of the scientific interpretation of the constitutional provisions, which embody the scientific concepts of recognizing the legal personality of the Ukrainian people in terms of belonging to the right of ownership of natural objects.

Purpose of the article: to consider and establish the main problems and prospects of forming a systematic approach to regulatory and legal support for land reform as a new paradigm, introducing into the current constitutional field of Ukraine the existing so-called land and agricultural reform, which has been carried out since independence.

\section{ANALYSIS OF RECENT RESEARCH AND PUBLICATIONS}

The unresolved nature of this problem forms a wide field of research in this area. Regarding the detailed description of the implemented measures and the technology of implementation of the state policy of land relations regulation in the scientific literature, the following developments are presented: of V.I. Andreitsev, M.M. Bahurynska, V.A. Boklah, M.V. Bochkov, M.P. Butko, O.M. Harnaha, B. M. Danylyshyn, A.S. Danylenko, D.S. Dobriak, B.V. Ierofeiev, A.I. Krysak, V.V. Lobanov, A.G. Martyn, A.M. Miroshnychenko, L.Ia. Novakovskyi, V.V. Nosik, A.A. Pohrebnyi, A.L. Pomazy-Ponomarenko, A.M. Tretiak, M.M. Fedorov, O.V. Khodakivska, G.I. Sharyi, M.V. Shulha and others. Modern scientific theoretical and methodological research and publications on the analysis of the state and search for ways to regulate land relations in the agrarian sphere are carried out by economists, land managers, jurists and other scientists, in particular: Haidutskyi P.I., Hladii M.V., Dobriak D.S., Dorosh I.M., Zaiats V.M., Evsiukov T.O., Luzan Iu.Ia., Lupenko Iu.O., Martyn A.G., Mesel-Veseliak V.Ia., Novakovskyi L.Ia., Paskhaver B.I., Sabluk P.T., Tretiak A.M., Fedorov M.M. and others.

Most scientists neglect objective assessments of transformational land processes carried out in Ukraine. They bypass the essence of the current constitutional land norms, focusing on the possible copying of useful principles of world experience, in particular market land relations. Modern research of these and other scientists is mainly reduced to finding ways to complete the ongoing land reforms and the introduction of the market for agricultural land.

Instead, O. Kovaliv, Doctor of Economics from the Institute of Agroecology and Nature Management of NAAS performed scientific and practical research, revealing a whole layer of reliable information about the actual state of transformation of land relations and nature management in Ukraine and analyzing the current state and consequences of reforms in Ukraine. In particular, he first revealed the essence of the constitutional norm «land and its natural resour- 
ces», which are natural objects of property of the Ukrainian people (Part 2 Article 14 Constitution of Ukraine) and cannot be in private, communal or state ownership. Such objects also cannot be the subject of sale and are not subject to alienation. Based on the provisions of the second part of Article 13 of the Constitution of Ukraine, O. Kovaliv notes that the right of ownership of the Ukrainian people (all citizens of Ukraine) to land and its natural resources as the main national wealth is revealed through «use» of natural objects of property resource and capital of the nation, not their «possession» or «disposal». That is, economic activity related to the use of natural objects of property of the Ukrainian people can be carried out only in the process of using them on a paid basis. The algorithm of acquisition and realization by citizens, legal entities and the state of property rights to land (land plots) as objects of civil rights (Part 2 Article 14 Constitution of Ukraine) is substantiated, which allows to «use» natural objects in accordance with law, which does not yet exist [3].

\section{MATERIALS AND METHODS}

The normative and information basis of the study is the Constitution of Ukraine, Ukrainian Legislation and bylaws, draft laws in the field of land relations, reports of the State Statistics Service of Ukraine and the State Land Cadastre, NAPC reports, case law of the European Court of Human Rights. The following research methods were used to perform the tasks set: monographic - elaboration of scientific publications and publications of the national press; logical - to determine social and economic trends; system approach - to improve state regulation of situational changes in the agricultural sector of the economy, in particular in land relations; empirical method - a comprehensive assessment of the current state; institutional analysis - to select effective mechanisms for regulating these relations; abstract-logical analysis - theoretical generalizations and formulation of conclusions; formalization method - to study the system of state regulation of land relations; methods of analysis and synthesis - to assess the dynamics, structure and effectiveness of the modern state policy.

\section{RESULTS AND DISCUSSION}

Thus, the changes began in the 1990s when agricultural land in the country belonged to the former state farms and collective farms, which were renamed «collective agricultural enterprises» (CAP) by the Law of February 14, 1992. On March 15, 1991, the Verkhovna Rada of Ukraine passed a resolution declaring all state-owned lands to be subject to land reform. Decree of the President of Ukraine of August 8, 1995 № 720/95 introduced the reform of CAP by granting their members land rights in the form of shares (plots) without specifying a specific physical location or defined boundaries. Subsequently, a mass process of allocating shares (plots) to land plots in kind (determined on the ground) was organized and acts on the ownership of specific land plots were issued.

On January 8, 2001, the Law of Ukraine "On Agreements on Expropriation of Land Share (Plot)» established that until the settlement of the procedure for exercising the rights of citizens and legal entities to land share (plot) by the Land Code of Ukraine, the owners of land shares (plots) may not temporarily enter into agreements on purchase and sale, donation of land shares (plots) or otherwise alienate these shares (plots) - except for their inheritance and redemption of land for state and public needs. In 2001 , a temporary moratorium was imposed, first for 1 year and then for 4 years. In 2004 and 2006 it was extended for a total of 3 years. In 2008, Land Code of Ukraine introduced a rule "the moratorium ends with the entry into force of laws on land cadastre and land market.» In 2010, changes were made - «the moratorium is valid until the adoption of the law on the land market, but expires no earlier than January 1, 2012.» Thus, from 2011 to 2018 , the moratorium was constantly extended.

To open the land market, on the basis of the Law of Ukraine "On State Land Cadastre» of July 7, 2011, the Electronic State Land Cadastre was launched in 2013.

On December 9, 2011, the parliament adopted in the first reading the draft Law "On the Land Market». The bill stipulated that only citizens of Ukraine, local governments and the state could acquire ownership of agricultural land. It was assumed that one citizen would not have the right to own land intended for commercial agricultural production, an area of more than 100 hectares or rent more than 6,000 hectares of such land in any one area or more than 5\% of land in any one area. Land cannot be sold at a price lower than the one determined by the expert, and the procedure must be established by law. The change of purpose of agricultural land, which previously belonged to the state, was prohibited for ten years after acquisition. After the first reading, the development of the bill stopped.

Thus, until 2019, the decisive factor was the moratorium on the sale of agricultural land (Paragraphs 14-15 Section X «Transitional Provisions» Land Code of Ukraine), which meant 
that landowners could not freely dispose of it. The reason for this is the Soviet legacy, as it was the communist leadership and pro-Soviet politicians who demanded a six-year moratorium in March 1991, when the first Ukrainian Land Code was adopted. Because of this, Soviet rudiments remained in the Ukrainian law, which are obstacles to effective reform.

Such a ban is applied, in addition to Ukraine, in Congo, Venezuela, Cuba, Tajikistan, North Korea, Belarus. The ban on disposing of one's property is a sign of an undemocratic state. The European Court of Human Rights in the case of Zelenchuk and Tsytsyura v. Ukraine on 22 May 2018 and Antonenko and Others v. Ukraine on 20 February 2020 declared the land moratorium a violation of the human right to dispose of their property guaranteed by Article 1 of the Protocol to the European Convention on Human Rights, as well as Article 41 of the Constitution of Ukraine, in the absence of an effective market for agricultural land, permanent extensions of the moratorium have made it indefinite, and the relevant legislation - unpredictable. Ukraine went beyond its wide discretion in this area and failed to ensure a fair balance between the general public interest and the applicants' property rights. According to the ECtHR, the Ukrainian authorities were extremely inconsistent in extending and modifying the moratorium and thus created legal uncertainty. The Ukrainian authorities cannot explain why the moratorium should be maintained, and if there were rational reasons for introducing a moratorium, they have lost their meaning over time and now they simply do not exist [3].

It is believed that the moratorium does not allow farms and large agricultural producers to buy land, deprives them of the opportunity to engage in long-term financial business planning. Land cannot be used to attract bank financing for the purchase of fuel, fertilizers, construction of storage facilities. The moratorium restricts farmers' access to financial resources and slows economic growth. The existence of a moratorium and the insecurity of land users' rights hinder the attraction of new technologies and investment in production with high added value.

As long as land relations are not legitimized, they are determined by the shadow market, which operates despite a formal moratorium. Transitional provisions of the Land Code prohibit the legal sale of land, change its purpose, make a right to a share in the authorized capital of the company, transfer it as collateral, but the sale is carried out informally through various schemes. Thousands of cases of land corruption can be found in the Unified Register of Judgments.
Unauthorized seizure of land is one of the most common forms of shadow use of the state land. Its essence is that a person without any grounds occupies a land plot and illegally uses it for his own benefit, and the community and the budget suffer losses. This scheme is being implemented in collusion with local authorities. Administrative (Article 53-1 of the Code of Administrative Offenses) and criminal (Article 197-1 of the Criminal Code) liability is provided for these actions.

State and municipal enterprises with large tracts of land enter into agreements with private entrepreneurs on joint activities. This type of contract under Art. 1132-1143 of the CCU and Article 176 of the Economic Code of Ukraine, allows the parties to carry out economic activities together without the formation of a single enterprise. In this way, enterprises receive state land for free use. The mentioned agreements stipulate that the business on the lands of state and communal enterprises implements its projects and shares profits with the owners. However, in practice, the owners do not make a profit. The decision to provide land for cultivation depends on the official, who disposes of the asset at his own discretion and is not regulated in any way, and information on concluded joint agreements and land assets of state-owned enterprises is not contained in any register. The areas of land of state-owned enterprises that are in the shade are measured in hundreds of thousands of hectares, and the losses of communities from unpaid rent are hundreds of millions of hryvnias.

According to the law, the moratorium does not apply to plots that are transferred to the ownership of citizens under the procedure of free privatization. According to Article 121 of Land Code of Ukraine, every citizen has the right to receive free of charge from the state or territorial community in any part of the country six plots, the total area of which can reach 6 hectares. This tool has become one of the largest sources of corruption in land relations and is still used for the shadow redistribution of state and communal lands. Despite decades of free privatization, there is no register of citizens who have received land under this procedure.

Emphyteusis is the right to use a land plot without any restriction on the term of validity, there are no requirements regarding the form, amount and terms of payment for use, which allows the landowner to pay the full amount at once for the entire period of use. The flexibility of this transaction has led to its widespread use as a tool for the actual purchase of land.

You can also get land in the property with a fictitious debt. To do this, the owner creates 
a debt secured by land, which is confirmed by a receipt. The court decision transfers the land to the creditor to repay the debt. Based on this decision, the registrar or notary subsequently changes the owner of the land plot in the Register of Real Rights.

In addition, you can transfer the land to the state or local community, for a bribe to change its purpose and sell after that, or rent shares, and then sell their corporate rights, or transfer shares under a lifetime maintenance agreement. Another common way to circumvent the moratorium is to enter into a land exchange agreement [4].

All of the above negates the numerous claims against the introduction of the land market, that it seems that it will be in the hands of large landowners, the peasants will lose the land and this land will be sold for nothing. Such as the real situation shows that the lack of a legal land market contributes to the impoverishment of the peasantry and the enrichment of corrupt business and government circles. In order for the shadow market for agricultural land to disappear, it is necessary to introduce a full-fledged land market, then the agreements will become transparent and legal.

On March 31, 2020, the Law of Ukraine «On Amendments to Certain Legislative Acts of Ukraine Concerning the Circulation of Agricultural Land» was adopted, according to which the moratorium on the sale of agricultural land will be lifted from June 2021. The law provides an opportunity to create transparent conditions for the acquisition of agricultural land by citizens of Ukraine.

According to the Law, until January 1, 2030, the sale price of agricultural land allocated in kind (on the ground) to the owners of land shares (plots) may not be less than their regulatory monetary value. The sale of land depends on the desire of the seller who will be able to choose a buyer and agree on a favorable price. In addition, it should be noted that under the new law, Ukrainians with the right of permanent use at a price equal to the normative monetary valuation of such land plots without holding a land auction. It is also important to limit the area of land owned by a person. Thus, in 2021-2023, only natural persons-citizens of Ukraine will be able to buy land up to 100 hectares per buyer; in 2023-2025 Ukrainian legal entities will be able to buy land up to 10 thousand hectares per company.

Citizens of Ukraine; legal entities of Ukraine, created and registered under the legislation of Ukraine, the participants (shareholders, members) of which are only citizens of Ukraine and / or the state, and / or territorial communities; territorial communities; state will be able to acquire the right of ownership of agricultural land plots.

Foreigners, stateless persons and legal entities are prohibited from acquiring shares in the authorized (composed) capital, shares, plots, membership in legal entities (except in the authorized (composed) capital of banks) that are owners of agricultural land. Acquisition of ownership of agricultural land by legal entities established and registered under the legislation of Ukraine, participants (founders) or ultimate beneficial owners (controllers) of which are persons who are not citizens of Ukraine, may be carried out from the date and subject to approval by referendum. Under any circumstances, the acquisition of ownership of agricultural land is prohibited for:

1) legal entities, participants (shareholders, members) or final beneficiaries of which are persons who are not citizens of Ukraine - for agricultural land of state and communal property, agricultural land allocated in kind (on the ground) to owners of land shares (plots), and which are located closer than 50 kilometers from the state border of Ukraine (except for the state border of Ukraine on sea);

2) legal entities, participants (shareholders, members) or final beneficiaries of which are citizens of a state recognized by Ukraine as an aggressor state or an occupying state;

3) persons, who are belonging to or belonged to terrorist organizations;

4) legal entities, participants (shareholders, members) or final beneficiaries of which are foreign states;

5) legal entities, which beneficial owner (controller) is impossible to establish;

6) legal entities, beneficial owners (controllers) of which are registered in offshore zones;

7) individuals and legal entities subject to special economic and other restrictive measures (sanctions).

It is also prohibited to alienate agricultural land located in the temporarily occupied territories of Donetsk and Luhansk oblasts, the Autonomous Republic of Crimea and the city of Sevastopol, except for their inheritance [21].

Land reform as a complex phenomenon today includes a number of other regulations, both already adopted and at the stage of bills. Regulatory support includes:

The Law of Ukraine «On Amendments to the Land Code of Ukraine and Certain Other Legislative Acts to Counteract Raiding» of December 5, 2019 automates the exchange of information between the register of rights and the land cadastre, obliges to digitize and enter infor- 
mation in the register of rights on paper, register prices of transactions with land.

Draft Law «On Amendments to Certain Legislative Acts Concerning the Sale of State and Communal Land Plots or Rights to Them (Leases, Superficies, Emphyteusis) through Electronic Auctions» Nr. 2195 introduces a transparent process of land electronic auctions and obliges to sell state and communal lands exclusively through such auctions.

Draft Law «On Amendments to the Land Code of Ukraine and Other Legislative Acts to Improve the Management and Deregulation System in the Sphere of Land Relations» Nr. 2194 simplifies land transfer procedures, decentralizes land management, transfers state lands outside settlements to communal ownership of communities and transfers control functions State Geocadastre to relevant local authorities.

"Law on National Infrastructure of Geospatial Data» adopted in April 13, 2020 opens free access to cadastral data.

«Law on Amendments to Certain Legislative Acts of Ukraine on Land Use Planning» Nr. 711-IX, which was adopted in June 17, 2020 and which will entry into force in July 24, 2021, will regulate the issue of establishing community boundaries, spatial planning of their territories.

Draft Law «On the Partial Guarantee Fund for Agriculture» Nr. 3205-1, which created the Credit Guarantee Fund for Small Producers, is currently out of consideration.

Analyzing the state of legal support for land reform in Ukraine today, it is difficult to disagree with the arguments of Doctor of Economics Oleksander Kovaliv (Kovaliv, 2021) on the need to introduce the so-called «land and agrarian reform» in the current constitutional field. After all, the consequences of non-implementation of constitutional norms are becoming more tangible, especially in rural areas, and negatively affect the functioning of natural agricultural landscapes, the state of soil fertility, the environment.

Kovaliv came to a number of conclusions, in particular: «The vast majority of Ukrainian scientists and educators, and hence their "students», who nurture in all branches of government (legislative, executive and judicial) and local government, ignoring the current Declaration of State Sovereignty Ukraine, later the Constitution of Ukraine, regarding land and its natural resources as natural objects of absolute property rights of the sovereign and independent Ukrainian people (all citizens), still apply pro-Soviet legislation, which was formulated for the enslaved peoples of the «Soviet Empire» on a known principle «Divide and rule».
Such «activity» also has a significant negative impact on the economic development of the state and is considered to destroy the constitutional order in Ukraine.

It is established that the Russian Federation, as the successor of the communist empire, continues to apply such norms, declaring in its Constitution (Article 9) literally: «1. Land and other natural resources are used and protected in the Russian Federation as the basis of life and activity of the peoples living in the respective territory. 2. Land and other natural resources may be in private, state, municipal and other forms of ownership.»

In contrast to the Constitution of Russia, the Basic Law of Ukraine (Part 1, Article 13) clearly and unambiguously declares: «Land, its subsoil, atmospheric air, water and other natural resources located within the territory of Ukraine, natural resources of its continental shelf, exclusive (marine) economic zone (abbreviated «land and its natural resources») are the objects of property of the Ukrainian people.»

Kovaliv proves that this unique formula «land and its natural resources» has become a cementing basis for Ukraine's becoming a sovereign and independent, democratic, social, legal state, extending to its entire territory of Ukraine as a unitary state. This current formula is different from the pro-imperial narrowing of the essence of the word «land» to the understanding «soil», «field» as «agricultural resource», where the word «land» is placed on a par with subsoil, forests, airspace, water and other natural resources, using the illusory unconstitutional expression «land and other natural resources».

Namely, in this way the Basic Law of Ukraine unequivocally recognizes all citizens of Ukraine as the sole and absolute owner of land as natural objects and does not allow the division of national property into "private», "communal (collective)» or even «state».

Therefore, since the adoption of the Constitution of Ukraine, it was required to delimit and demarcate the border and full nominal registration of all citizens of Ukraine, to record and take on the full balance of the owner (citizens of Ukraine) all natural objects (resources), providing a fully functioning National Cadastre objects, including the State Cadastre of Soils in Agricultural Landscapes of Ukraine (State Cadastre of Agrosphere of Ukraine), monitoring and control. For this purpose, a relevant non-departmental National Land Institution, such as the National Bank of Ukraine, was to be established. Unfortunately, these fundamental steps have not been taken.

At the same time, it is far-fetchedly proved, especially by many lawyers, that these «sing- 
le-row» natural resources (natural objects) as different categories of «land», especially «agricultural land», belong to the objects of civil rights (can be purchased or sold). Thus, deriving them from the constitutional legal field of "property», the declared absolute property right of the sovereign (people) is spontaneously divided into three different forms of civil property rights: «state», «communal (collective)» and «private».

Declared constitutional rights of citizens of Ukraine (Articles 13 and 14, 41) regarding land relations and the use of nature require a clear and unambiguous interpretation by the Constitutional Court of Ukraine and unprecedented implementation by all branches of government current land norms of the Basic Law of Ukraine, adopting timely adequate legislative, executive and the judiciary, as well as monitoring their implementation under the watchful eye of real civil society institutions...» [34].

All these and other circumstances motivate us to consider and establish the main problems and prospects of forming a systematic approach to regulatory and legal support for land reform as a new paradigm, introducing the existing socalled land and agrarian reform into the current constitutional field of Ukraine.

\section{CONCLUSIONS}

Regulatory and legal support of land reform in Ukraine is going through a difficult path of formation and overcoming obstacles in the transition from the administrative-command system of economic management to the market one. Until now, there are no laws in the national legislation that would regulate the acquisition and implementation of land ownership (land plots) for the purpose of using the natural objects of ownership of the Ukrainian people. Instead, the existence of Soviet vestiges in the legislation and the long-standing existence of an artificial and unjustified moratorium on the sale of agricultural land violated the rights and interests of citizens and the state itself. This has negatively affected economic growth, investment, technology and production, the environment and living standards in rural areas, as well as their role in the prosperity of the corrupt and shadow economy in the country. Such activities have given rise to numerous shadowy corruption schemes to circumvent the moratorium.

In 2020, there was a significant leap in the development of regulatory and legal support for land reform as a result of the adoption of the Law of Ukraine "On Amendments to Certain Legislative Acts of Ukraine on the Circulation of Agricultural Land». This law seems to be motivated and necessary given the existing problems of regulating the circulation of agricultural land. However, the Law has only begun the transformation and does not address all of the above issues. Regulatory support for reform should be based on the rule of law and the principles of sustainability, transparency, fairness and inclusiveness. Requirements to change the functionality of the State Geocadastre of Ukraine have intensified.

Directions for further reforms and expansion of the legal framework should be based on the current provisions of the Constitution of Ukraine, which establish the property rights of the Ukrainian people, as they are the norms of direct action and can not be neglected. The Ukrainian people (all citizens) must be a full-fledged subject of ownership of the main national wealth - natural objects of ownership of the people - land and its natural resources (subsoil, soils, forests, air, water and other resources), which are not subject alienation, it is possible only to use them on a paid basis according to established regulations.

\section{REFERENCES}

1. Konstytutsiia Ukrainy vid 28 chervnia 1996 [The Constitution of Ukraine from June 28, 1996]. (1996). Vidomosti Verkhovnoi Rady Ukrainy - Bulletin of Verkhovna Rada of Ukraine, 30 [in Ukrainian].

2. Dobriak, D. S., Shkuratov, O. I. (2018). Formuvannia i rozvytok rynkovykh zemelnykh vidnosyn na terenakh Ukrainy [Formation and development of market land relations in Ukraine]. Zbalansovane pryrodokorystuvannia - Balanced nature management, 1, 8-17 [in Ukrainian].

3. Kovaliv, O. I. (2016). Zvershennia zemelnoi reformy v Ukraini: nova paradyhma: monohrafiia [Completion of land reform in Ukraine: a new paradigm: a monograph]. Kyiv: DIA [in Ukrainian].

4. Rishennia Yevropeiskoho sudu z prav liudyny vid 22.05.2018 spravi «Zelenchuk i Tsytsiura proty Ukrainy» [Judgment of the European Court of Human Rights of May 22, 2018 in the case of Zelenchuk and Tsytsyura v. Ukraine]. Zaiavy № 846/16 ta № 1075/16 - Applications No 846/16 and No $1075 / 16$. URL: https://zakon.rada.gov.ua/laws/show/974_c79\#Text. [in Ukrainian].

5. Skhemy tinovoho obihu zemli v umovakh moratoriiu: analitychnyi ohliad. [Shadow circulation schemes under a moratorium: an analytical review]. (2020). NAZK NAPC [in Ukrainian].

6. Zemelnyi kodeks Ukrainy: Zakon Ukrainy vid 18.12.1990 [Land Code of Ukraine: Law of Ukraine from December 18 th 1990 ]. (1990). 561-XII URL: https://zakon.rada.gov.ua/laws/show/561-12\#Text [in Ukrainian]. 
7. Pro vnesennia zmin i dopovnen do Zemelnoho kodeksu Ukrainskoi RSR: Zakon Ukrainy vid 13.03. 1992. [On Amendments to the Land Code of the Ukrainian SSR: Law of Ukraine of March 13th, 1992]. (1992). 2196-XII URL:https://zakon.rada.gov.ua/laws/show/2196-12\#Text [in Ukrainian].

8. Pro kolektyvne silskohospodarske pidpryiemstvo: Zakon Ukrainy vid 14.02.1992 [On Collective Agricultural Enterprise: Law of Ukraine of February 14th, 1992]. (1992). 2114-XII URL: https://zakon.rada. gov.ua/laws/show/2114-12\#Text [in Ukrainian].

9. Pro poriadok paiuvannia zemel, peredanykh u kolektyvnu vlasnist silskohospodarskym pidpryiemstvam i orhanizatsiiam: Ukaz Prezydenta Ukrainy vid 08.08.1995 [On the procedure for distribution of lands transferred to collective ownership to agricultural enterprises and organizations: Decree of the President of Ukraine of August 8th, 1995]. (1995). 720/95 URL: https://zakon.rada.gov.ua/laws/ show/720/95\#Text [in Ukrainian].

10. Pro nevidkladni zakhody shchodo pryskorennia reformuvannia ahrarnoho sektora ekonomiky: Ukaz Prezydenta Ukrainy vid 03.12.1999 [On urgent measures to accelerate the reform of the agricultural sector of the economy: Decree of the President of Ukraine of December 3-rd, 1999]. (1999). 1529/99 URL: https://zakon.rada.gov.ua/laws/show/1529/99\#Text [in Ukrainian].

11. Pro vnesennia zmin do Zemelnoho kodeksu Ukrainy: Zakon Ukrainy vid 06.10.2004 [On Amendments to the Land Code of Ukraine: Law of Ukraine of October $\left.6^{\text {th }}, 2004\right]$. (2004). 2059-IV URL: https://zakon. rada.gov.ua/laws/show/2059-15\#Tex [in Ukrainian].

12. Pro vnesennia zmin do Zemelnoho kodeksu Ukrainy shchodo zaborony prodazhu zemel silskohospodarskoho pryznachennia do pryiniattia vidpovidnykh zakonodavchykh aktiv: Zakon Ukrainy vid 19.12.2006 [On Amendments to the Land Code of Ukraine Prohibiting the Sale of Agricultural Land Until the Adoption of Relevant Legislative Acts: Law of Ukraine of December 19 $\left.{ }^{\text {th }}, 2006\right]$. (2006). 490-V URL: https://zakon.rada.gov.ua/laws/show/490-16\#Text [in Ukrainian].

13. Pro vnesennia zmin do deiakykh zakonodavchykh aktiv Ukrainy: Zakon Ukrainy vid 03.06 .2008 [On Amendments to Certain Legislative Acts of Ukraine: Law of Ukraine of June 3rd, 2008]. (2008). 309-VI URL: https://zakon.rada.gov.ua/laws/show/309-17\#Text [in Ukrainian].

14. Pro vnesennia zmin do punktiv 14 i 15 rozdilu $\mathrm{X}$ «Perekhidni polozhennia» Zemelnoho kodeksu Ukrainy shchodo terminu na prodazh zemelnykh dilianok: Zakon Ukrainy vid 19.01.2010 [On Amendments to Paragraphs 14 and 15 of Section X «Transitional Provisions» of the Land Code of Ukraine on the Term for the Sale of Land Plots»: Law of Ukraine of January 19 ${ }^{\text {th }}$, 2010]. (2010). 1783-VI URL: https://zakon.rada.gov.ua/laws/show/1783-17\#Text [in Ukrainian].

15. Pro vnesennia zmin do rozdilu $\mathrm{X}$ «Perekhidni polozhennia» Zemelnoho kodeksu Ukrainy shchodo zaborony na vidchuzhennia ta zminu tsilovoho pryznachennia zemel silskohospodarskoho pryznachennia: Zakon Ukrainy vid 20.12.2011 [On Amendments to Section X «Transitional Provisions « of the Land Code of Ukraine on the Prohibition of Alienation and Cange of Purpose of Agricultural Land: Law of Ukraine of December 20th 2011 ]. (2011). 4174-VI URL: https://zakon.rada.gov.ua/laws/show/1783-17\#Text [in Ukrainian].

16. Pro vnesennia zmin do Zemelnoho kodeksu Ukrainy: Zakon Ukrainy vid 20.11.2012 [On Amendments to the Land Code of Ukraine: Law of Ukraine of November 20th 2012 ]. (2012). 5494-VI URL: https:// zakon.rada.gov.ua/laws/show/5494-17\#Text [in Ukrainian].

17. Pro vnesennia zmin do rozdilu $\mathrm{X}$ «Perekhidni polozhennia» Zemelnoho kodeksu Ukrainy shchodo prodovzhennia zaborony vidchuzhennia silskohospodarskykh zemel: Zakon Ukrainy vid 10.11.2015 [On Amendments to Section X «Transitional Provisions» of the Land Code of Ukraine on the Extension of the Prohibition of the Alienation of Agricultural Land: Law of Ukraine of November 10th, 2015]. (2015). 767-VIII URL: https://zakon.rada.gov.ua/laws/show/767-19\#Text [in Ukrainian].

18. Pro vnesennia zminy do rozdilu $\mathrm{X}$ «Perekhidni polozhennia»Zemelnoho kodeksu Ukrainy shchodo prodovzhennia zaborony vidchuzhennia silskohospodarskykh zemel: Zakon Ukrainy vid 06.10.2016 [On Amendments to Section X «Transitional Provisions» of the Land Code of Ukraine to Extend the Prohibition of Alienation of Agricultural Land: Law of Ukraine of October 6 $\left.{ }^{\text {th }}, 2016\right]$. (2016). 1669-VIII URL: https://zakon.rada.gov.ua/laws/show/2768-14\#Text [in Ukrainian].

19. Pro vnesennia zminy do rozdilu $\mathrm{X}$ «Perekhidni polozhennia» Zemelnoho kodeksu Ukrainy: Zakon Ukrainy vid 07.12.2017. [On Amendments to Section X «Transitional Provisions» of the Land Code of Ukraine: Law of Ukraine of December $7^{\text {th }}$, 2017]. 2017. 2236-VIII URL: https://zakon.rada.gov.ua/laws/ show/2236-19\#Text [in Ukrainian].

20. Pro vnesennia zmin do rozdilu $\mathrm{X}$ «Perekhidni polozhennia» Zemelnoho kodeksu Ukrainy shchodo prodovzhennia zaborony vidchuzhennia silskohospodarskykh zemel: Zakon Ukrainy vid 20.12.2018 [On Amendments to Section X «Transitional Provisions» of the Land Code of Ukraine on the Extension of the Prohibition of the Alienation of Agricultural Land: Law of Ukraine of December 20th, 2018]. (2018). 2666-VIII URL: https://zakon.rada.gov.ua/laws/show/2666-19\#Text [in Ukrainian].

21. Pro vnesennia zmin do deiakykh zakonodavchykh aktiv Ukrainy shchodo obihu zemel silskohospodarskoho pryznachennia: Zakon Ukrainy vid 31.03.2020 [On Amendments to Certain Legislative Acts of Ukraine Concerning the Circulation of Agricultural Lands: Law of Ukraine of March 3st, 2020]. (2020). 552-IX URL: https://zakon.rada.gov.ua/laws/show/552-20\#Text [in Ukrainian]. 
Regulatory and legal support of land reform

in Ukraine

22. Pro vnesennia zmin do deiakykh zakonodavchykh aktiv Ukrainy shchodo protydii reiderstvu: Zakon Ukrainy vid 05.12.2019 [On Amendments to Certain Legislative Acts of Ukraine Concerning Anti-Raiding: Law of Ukraine of December $5^{\text {th }}, 2019$ ]. (2019). 340-IX URL: https://zakon.rada.gov.ua/laws/ show/340-20\#Text [in Ukrainian].

23. Pro vnesennia zmin do deiakykh zakonodavchykh aktiv shchodo prodazhu zemelnykh dilianok derzhavnoi ta komunalnoi vlasnosti abo prav na nykh (orendy, superfitsiiu, emfitevzysu) cherez elektronni auktsiony: Proekt Zakonu vid 01.10.2019 [On Amendments to Certain Legislative Acts Concerning the Sale of State and Communal Land Plots or Rights to Them (Leases, Superficies, Emphyteusis) through Electronic Auctions: Draft Law of October 1st, 2019]. (2019). 2195 URL: https://zakon.rada.gov. ua/laws/show/1423-20\#Text [in Ukrainian].

24. Pro vnesennia zmin do Zemelnoho kodeksu Ukrainy ta inshykh zakonodavchykh aktiv shchodo udoskonalennia systemy upravlinnia ta derehuliatsii u sferi zemelnykh vidnosyn: Proekt Zakonu vid 01.10.2019 [On Amendments to the Land Code of Ukraine and Other Legislative Acts on Improving the System of Management and Deregulation in the Field of Land Relations: Draft Law of October 1st, 2019]. (2019). 2194 URL: http://w1.c1.rada.gov.ua/pls/zweb2/webproc4_1?pf3511=66970 [in Ukrainian].

25. Pro natsionalnu infrastrukturu heoprostorovykh danykh: Proekt Zakonu vid 01.11.2019. [«On National Geospatial Data Infrastructure Draft Law of November 1st, 2019 2370]. (2019). URL: http://w1.c1.rada. gov.ua/pls/zweb2/webproc4_1?pf3511=67268 [in Ukrainian].

26. Pro vnesennia zmin do Zeme-noho kodeksu Ukrainy ta inshykh zakonodavchykh aktiv shchodo planuvannia vykorystannia zemel: Proekt Zakonu vid 17.10.2019. [On Amendments to the Land Code of Ukraine and Other Legislative Acts on Land Use Planning: Draft Law of October 17 th, 2019]. (2019). 2280 URL: http://w1.c1.rada.gov.ua/pls/zweb2/webproc4_1?pf3511=67111 [in Ukrainian].

27. Pro Fond chastkovoho harantuvannia kredytiv u silskomu hospodarstvi: Proekt Zakonu vid 10.02.2020. [On the Partial Guarantee Fund for Agriculture Loans: Draft Law of February 10th, 2020]. (2020). 3047 URL: http://w1.c1.rada.gov.ua/pls/zweb2/webproc4_1?pf3511=68102 [in Ukrainian].

28. Ambrosov, V.Ia. \& Marenych, T.G. (2009). Rozvytok zemelnoho rynku ta ipotechne kredytuvannia. [Land Market Development and Mortgage Lending]. Ekonomika APK - Economics of agro-industrial complex 10, 104-108 [in Ukrainian].

29. Artiushyn, V.I., Kobets, M.I. \& Pugachov M.I. (2007).Problemy stanovlennia ta funktsionuvannia rynku zemel silskohospodarskoho pryznachennia v Ukraini. [Problems of Formation and Functioning of the Market of Agricultural Lands in Ukraine]. Kyiv: Analitychno-doradchyi tsentr Blakytnoi strichky $P R O O N$ [in Ukrainian].

30. Vivcharenko, O.A. (2005). Harantii prava vlasnosti na zemliu v Ukraini [Guarantees of Land Ownership in Ukraine] Extended abstract of candidate's thesis. Kyiv [in Ukrainian].

31. Virchenko, O.V. (2013). Derzhavne rehuliuvannia zemelnykh vidnosyn v umovakh formuvannia rynku zemel silskohospodarskoho pryznachennia [State Regulation of Land Relations in the Conditions of Formation of the Market of Agricultural Lands] Business Inform, 10, 207-211 [in Ukrainian].

32. Zaiats, V.M. Rozvytok rynku silskohospodarskykh zemel: monohrafiia [Development of the market of agricultural lands: monograph]. Kyiv: NNTs «IAE» [in Ukrainian].

33. Kovaliv, O. I. (2021, May 7-8). Rosiiskyi «slid»v reformi rynku zemli [Russian «trace» in the reform of the land market] Den-Day, 81-82, 11 [in Ukrainian].

\title{
НОРМАТИВНО-ПРАВОВЕ ЗАБЕЗПЕЧЕННЯ ПРОВЕДЕННЯ ЗЕМЕЛЬНОЇ РЕФОРМИ В УКРАЇНI
}

\author{
А.О. Заіка \\ аспірант \\ Інститут агроекології і природокористування НААН (м. Київ, Україна) \\ e-mail:anastasia05091995@gmail.com; \\ ORCID: https://orcid.org/0000-0002-4260-4190
}

Висвітлено процес становлення нормативно-правового забезпечення проведення земельноаграрної реборми в Україні в історичній ретроспективі.

Встановлено, шо причиною основних проблем у здійсненні реборми є наявність радянсъких рудиментів у законодавстві та політикумі України.

Досліджено стан відсутності повноиінної інституалізаиїі конституиійних земелъних норм та існування довгострокового мораторію на продаж земель сільсъкогосподарсъкого призначення, що негативно вплинуло на економічне зростання, інвестиційну діяльність, розвиток технологій та виробництва, стан довкілля $і$ рівенъ життя в сілъсъкій місщевості, а також їх ролъ у проивітанні корупційної й тінъової економіки в державі. 
Проаналізовано якісно новий етап нормативно-правового регулювання ринку земель сілъсъкогосподарсъкого призначення, який почався у 2020 роиі з прийняттям Закону Украӥни «Про внесення змін до деяких законодавчих актів України щодо обігу земель сільсъкогосподарсъкого призначення» та супутніх норлативно-правових актів.

Зроблено висновки щодо необхідності та вмотивованості подальшого розвитку законодавства в галузі регулювання земельних та суспільних відносин як ринкових.

Окреслено необхідні напряли подальшого реgормування та розширення нормативно-правової бази.

Ключові слова: конституизйні норми, ринок землі, мораторій, пай, обіг земель сілъсъкогосподарсъкого призначення, законодавство.

\section{ЛITEPATУРА}

2. Конституція України від 28 червня 1996. Відомості Верховної Ради України. 1996. № 30.

3. Добряк Д.С., Шкуратов О.І. Формування і розвиток ринкових земельних відносин на теренах України. Збалансоване природокористування. 2018. № 1. С. 8-17.

4. Ковалів О.I. Звершення земельної реформи в Україні: нова парадигма: монографія / O.I. Ковалів. К.: ДІА. 2016. 416 с.

5. Рішення Європейського суду з прав людини від 22.05.2018 р. у справі «Зеленчук і Цицюра проти України» (Заяви № 846/16 та № 1075/16). URL: https://zakon.rada.gov.ua/laws/show/974_c79\#Text (дата звернення: 24.04.2021).

6. Схеми тіньового обігу землі в умовах мораторію: аналітичний огляд. НАЗК, грудень 2020.

7. Земельний кодекс України: Закон України від 18 грудня 1990 року № 561-XII. URL: https: //zakon. rada.gov.ua/laws/show/561-12\#Text (дата звернення: 25.04.2021).

8. Про внесення змін і доповнень до Земельного кодексу Української РСР: Закон України від 13 березня 1992 року № 2196-XII. URL: https://zakon.rada.gov.ua/laws/show/2196-12\#Tеxt (дата звернення: 25.04.2021).

9. Про колективне сільськогосподарське підприємство: Закон України від 14 лютого 1992 року № 2114-XII. URL: https://zakon.rada.gov.ua/laws/show/2114-12\#Tехt (дата звернення: 25.04.2021).

10. Про порядок паювання земель, переданих у колективну власність сільськогосподарським підприємствам і організаціям : Указ Президента України від 08.08.1995 № 720/95. URL: https://zakon.rada. gov.ua/laws/show/720/95\#Text (дата звернення: 25.04.2021).

11. Про невідкладні заходи щодо прискорення реформування аграрного сектора економіки: Указ Президента України від 03.12.1999 № 1529/99. URL: https://zakon.rada.gov.ua/laws/show/1529/99\#Text (дата звернення: 25.04.2021).

12. Про внесення змін до Земельного кодексу України: Закон України від 6 жовтня 2004 року № 2059 IV. URL: https://zakon.rada.gov.ua/laws/show/2059-15\#Tеxt (дата звернення: 25.04.2021).

13. Про внесення змін до Земельного кодексу України щодо заборони продажу земель сільськогосподарського призначення до прийняття відповідних законодавчих актів : Закон України від 19 грудня 2006 року № 490-V.URL: https://zakon.rada.gov.ua/laws/show/490-16\#Tехt (дата звернення: 25.04.2021).

14. Про внесення змін до деяких законодавчих актів України : Закон України від 3 червня 2008 року № 309-VI. URL: https://zakon.rada.gov.ua/laws/show/309-17\#Text (дата звернення: 26.04.2021).

15. Про внесення змін до пунктів 14 і 15 розділу $\mathrm{X}$ «Перехідні положення» Земельного кодексу України щодо терміну на продаж земельних ділянок: Закон України від 19 січня 2010 року № 1783-VI. URL: https://zakon.rada.gov.ua/laws/show/1783-17\#Text (дата звернення: 26.04.2021).

16. Про внесення змін до розділу $\mathrm{X}$ «Перехідні положення» Земельного кодексу України щодо заборони на відчуження та зміну цільового призначення земель сільськогосподарського призначення : Закон України від 20 грудня 2011 року № 4174-VI. URL: https://zakon.rada.gov.ua/laws/show/4174-17\#Text (дата звернення: 26.04.2021).

17. Про внесення змін до Земельного кодексу України: Закон України від 20 листопада 2012 року № 5494-VI. URL: https://zakon.rada.gov.ua/laws/show/5494-17\#Text (дата звернення: 26.04.2021).

18. Про внесення змін до розділу $\mathrm{X}$ «Перехідні положення» Земельного кодексу України щодо продовження заборони відчуження сільськогосподарських земель: Закон України від 10 листопада 2015 року № 767-VIII. URL: https://zakon.rada.gov.ua/laws/show/767-19\#Tехt (дата звернення: 26.04.2021)

19. Про внесення зміни до розділу $\mathrm{X}$ «Перехідні положення» Земельного кодексу України щодо продовження заборони відчуження сільськогосподарських земель: Закон України від 6 жовтня 2016 року № 1669-VIII. URL: https://zakon.rada.gov.ua/laws/show/2768-14\#Tеxt (дата звернення: 26.04.2021)

20. Про внесення зміни до розділу $\mathrm{X}$ «Перехідні положення» Земельного кодексу України: Закон Украї- 
ни від 7 грудня 2017 року № 2236-VIII. URL: https://zakon.rada.gov.ua/laws/show/2236-19\#Text (дата звернення: 26.04.2021)

21. Про внесення змін до розділу $\mathrm{X}$ «Перехідні положення» Земельного кодексу України щодо продовження заборони відчуження сільськогосподарських земель: Закон України від 20 грудня 2018 року № 2666-VIII. URL: https://zakon.rada.gov.ua/laws/show/2666-19\#Tеxt (дата звернення: 26.04.2021)

22. Про внесення змін до деяких законодавчих актів України щодо обігу земель сільськогосподарського призначення : Закон України від 31 березня 2020 року №552-IX. URL: https://zakon.rada.gov.ua/ laws/show/552-20\#Text (дата звернення: 26.04.2021).

23. Про внесення змін до деяких законодавчих актів України щодо протидії рейдерству: Закон України від 05.12.2019 № 340-IX.URL: https://zakon.rada.gov.ua/laws/show/340-20\#Tехt (дата звернення: 26.04.2021).

24. Про внесення змін до деяких законодавчих актів щодо продажу земельних ділянок державної та комунальної власності або прав на них (оренди, суперфіцію, емфітевзису) через електронні аукціони: Проект Закону № 2195 від 01.10.2019. URL: https://zakon.rada.gov.ua/laws/show/1423-20\#Text (дата звернення: 26.04.2021).

25. Про внесення змін до Земельного кодексу України та інших законодавчих актів щодо удосконалення системи управління та дерегуляції у сфері земельних відносин : Проект Закону № 2194 від 01.10.2019. URL: http://w1.c1.rada.gov.ua/pls/zweb2/webproc4_1?pf3511=66970 (дата звернення: 26.04.2021).

26. Про національну інфраструктуру геопросторових даних: Проект Закону № 2370 від 01.11.2019. URL: http://w1.c1.rada.gov.ua/pls/zweb2/webproc4_1?pf3511=67268 (дата звернення: 26.04.2021).

27. Про внесення змін до Земельного кодексу України та інших законодавчих актів щодо планування використання земель: Проект Закону № 2280 від 17.10.2019. URL: http://w1.c1.rada.gov.ua/pls/ zweb2/webproc4_1?pf3511=67111 (дата звернення: 26.04.2021).

28. Про Фонд часткового гарантування кредитів у сільському господарстві: Проект Закону № 3047 від 10.02.2020. URL: http://w1.c1.rada.gov.ua/pls/zweb2/webproc4_1?pf3511=68102 (дата звернення: 26.04.2021).

29. Амбросов В.Я., Маренич Т.Г. Розвиток земельного ринку та іпотечне кредитування. Економіка АПК. 2009. 10. C. $104-108$.

30. Артюшин B.I., Кобець M.I., Пугачов M.I. Проблеми становлення та функціонування ринку земель сільськогосподарського призначення в Україні. К.: Аналітично-дорадчий центр Блакитної стрічки ПРООН, 2007.

31. Вівчаренко, О.А. Гарантії права власності на землю в Україні: авторефр. дис. канд. юрид. наук: 12.00 .06$. 2005.

32. Вірченко, О. В. Державне регулювання земельних відносин в умовах фрормування ринку земель сільськогосподарського призначення. Бізнес Інфрорм. 2013. 10: 207-211.

33. Заяць В.M. Розвиток ринку сільськогосподарських земель: монографрія. К.: ННЦ «IAE», 2012.390 с.

34. Ковалів О.І. Російський «слід» в реформі ринку землі. День. 2021. 7-8 трав. № 81-82. С. 11.

\section{ВІДОМОСТІ ПРО АВТОРА}

Заіка Анастасія Олександрівна, аспірант, Інститут агроекології і природокористування НААН (вул. Метрологічна, 12, м. Київ, Україна, 03143; e-mail: anastasia05091995@gmail.com; ORCID: https://orcid.org/0000-0002-4260-4190) 